\title{
Factors Affecting Saving Practices of Members of Rural\&Urban Saving and Credit Cooperatives: Evidence from Kucha Woreda, Gamo Gofa Zone, Snnprs, Ethiopia
}

\author{
Tefera Tanga \\ Msc in Accounting, Higher Government Expert \\ Biniyam Belachew Lemma \\ MA in Development Management, Executive Director and \\ Amen Diakon Debebe \\ MA in Development Management), Lecturer at Wolaita Sodo University
}

\begin{abstract}
The study was conducted to assess factors affecting saving practices of members of saving and credit cooperatives (SACCOs) in Gamo Gofa zone kucha woreda of SNNP region, Ethiopia. The study was achieved on selected 392 respondents. The selection of members was done using simple random sampling method based on convenient sampling method due to time and budget constraints. Semi structured questionnaire was administered by interviewing each respondent and filling the questionnaire. A response rate of $100 \%(392$ respondents) was achieved. Data was analyzed using multiple linear regression model to test relationships between the dependent and independent variables included in the study. The dependent variable is saving practice of SACCOs members and the independent variables are annual income, training participation, credit received from the SACCOs, age of the respondent, dependency ratio, family size, education status, savings before joining the SACCO, and contribution of family members of their livelihood. The members of SACCOs save if they are provided with trainings and credit as per their need and their income level and education status also affect their saving level. Therefore, the following major recommendations were made: government, NGOs and other stakeholders should work on strengthening the capacities of SACCOs to enable them provide customized trainings for their members, appropriate credit services like increasing the amount of credit they provide through linkage with other financial institutions and arrangement of injection of outside money and activities which can increase the level and diversification of income of their members in order to mobilize savings effectively and efficiently.
\end{abstract}

Keywords: Saving practices, SACCOs, Members

DOI: $10.7176 / J E S D / 10-1-02$

\subsection{BACKGROUND OF THE STUDY}

Saving is the portion of income not spent on current expenditures or as income that is not consumed immediately by buying goods and services. Because, a person does not know what will happen in the future, money should be saved to pay for unexpected events or emergencies. Without savings, unexpected events can become large financial burdens. Therefore, savings helps an individual or organizations to be financially secured (Lisa and Jeffers, 2009).

Although rural savings and credit cooperatives (RUSACCOs) are newly emerging institutions, most of them have started providing at least savings and then credit services to their members. To this effect, the need to focus on the establishment of new and strengthening of existing rural saving and credit cooperatives is important. Saving and credit cooperatives are member owned financial institutions in which membership is open and voluntary. They are not regulated by the National Bank of Ethiopia (NBE) which is the central bank in Ethiopia.

The primary focus of the government was especially in urban and semi urban areas in the banking sector. By increasing the number of branches and providing incentives for savers like prizes, the government owned commercial bank (that means the Commercial Bank of Ethiopia) had been trying to change the saving culture of the society; especially to the very poor people (Commercial Bank of Ethiopia web site, 2012).

However, as compared to the demand for the services microfinance institutions coverage was very small. Many of the formal financial institutions in the rural areas including commercial banks, microfinance institutions and cooperatives appear to had failed to provide saving facilities that were acceptable and attractive to rural dwellers. This was because, many rural inhabitants still save values in kind or patronize traditional savings and credit associations to save for unexpected future events (Nwankwo, et, al 2013). It was undebatable that cooperatives had the most prolonged and successful experience in the mobilization of micro savings and micro lending which were the crucial factors for income generation (German Cooperative and Raiffiesen confederation, 2005). 
As the literature reveals, apart from the existence of suitable financial intermediation, there were different factors that can affect saving decision of individuals. In this regard, Nwankwoet.al, (2013: 215) noted that most economists agree income and/or wealth was the main driving force behind consumption and thus saving. However, these economists disagree on which income should be applied. The Keynesians used current/absolute income, Freidman permanent income, Modigliani developed his own consumption theory based on the permanent income over the life-cycle of an individual, and Duesembery focused on relative income. However, there were other factors that may affect saving practice of individuals which was specific to the socio-economic situation of them (Nwankwo et.al, 2013).

A study which had been done on determinants of savings of rural and urban households/individuals show some significant factors were affecting saving. According to (Girma, et.al, 2013) nine variables were found to had a significant effect on saving level of households. These variables were household head education level, livestock holdings, access to credit service, income, and investment, training participation, contact with extension agents, and forms of savings and saving motives. The result of the study shows that rural households do save regardless of their low income mainly in informal saving institutions showing high request for accessibility for formal saving institutions. Therefore, this study is aimed at assessing factors affecting saving practices of members of rural \& urban saving and credit cooperatives the case of Kucha Woreda, Gamo Gofa Zone, SNNPRS, Ethiopia.

\subsection{STATEMENT OF THE PROBLEM}

Most rural peoples have less awareness about saving, have less income, have no organized financial institutions(financial institutions has no furniture, own office, cash safe box)and fear of Derg cooperative (cooperatives committee cheating and frauding of individual member asset). Due to this lack of awareness peoples saved less amount from their own income (kucha woreda cooperative development office,2008).

Financial services, such as saving, credit and insurance can be provided by formal and/or informal financial institutions/providers. Informal financial sector refers to economic entities (individuals, associations, nonfinancial business firms) that are engaged in saving mobilization and provision of credit outside the control of monetary and financial policies, that was, they are neither legally licensed, nor registered in the government agencies. Formal providers were those who are subject to banking laws of the country of operation. These include Central banks, development banks, Microfinance Institutions, Saving and Credit Cooperatives, Insurance Companies etc that were engaged in diversified financial intermediation(Al-bagdadi, H., and Bruntrup, M. (2002).

As a result of these and other constraints, they mobilize low saving which results in lack of own source of loan able funds to lend to their members. This, in turn, will result in lack of access to credit by members and it will eventually restrain them from investment and income generation which ultimately limit their saving (SNNPR Marketing and Cooperative bureau report, 2013). .

Furthermore, these cooperatives have not supported by any other body they needed assistance they deserve to enable them exploit their unique position in the rural areas to encourage thrifts among their members and to mobilize savings for investment purposes (Cheruiyot et al, 2012).

As the best knowledge of the researcher, no research work has been done empirically about factors affecting saving practices of members of SACCOs in the study area. Hence, this study tried to fill this gap and assess the factors that affect the saving practices of members of SACCOs from both members and cooperatives perspective.

Hence, the purpose of this paper was to assess the main factors that affect saving practices of members of SACCOs in SNNPG region of Ethiopia particularly in Gamo Gofa zone kucha woreda and propose possible recommendations so that these institutions as well as the government body and other government projects like livelihood and rural financial intermediate program me (RuFIP )working with them could employ efficient strategies to mobilize saving from the rural and urban society, the study was focused on factors affecting saving performances of rural and urban saving and credit cooperatives (SACCOs) and their members.

\subsection{RESEARCH OBJECTIVES:}

The overall objective of the study is to assess factors affecting saving practices of members of rural and urban saving and credit cooperatives (SACCOs) the case of Gamo Gofa zone kucha woreda.

The Specific objectives of this study are the followings:

* To identify the relationship between annual incomes of individual members, credit access and financial literacy training participation, and their saving practice in SACCOs.

* To examine the relationship between saving before membership, family members' contribution for their livelihood and saving practices of members.

* To identify the relationship between demographic variables like age, family size, education status, and dependency ratio and saving practice of members of SACCOs. 


\subsection{REVIEW OF RELATED LITERATURE:}

\subsubsection{Theoretical and conceptual literature review}

Saving your money is one of the most important things you can do to gain some security in your financial situation. Whether you just want to smooth your consumption, be prepared for emergencies or start your own business, savings can help you arrive at your goals while creating minimal risks. Savings are money that is put away in the present for use in the future. Savings are investments in jewelers or animals that can be sold when cash is needed. Savings are a way of building assets which can be sold for cash if needed. Savings are a fundamental part of money management. Savings can come in different forms, and can help you to reach many different financial goals, whether you want to be able to better handle shocks like illness in the family or be able to grow your business more (Pailwar V.K, 2010).

Informal savings include saving cash at home, which keeps your cash very accessible and allows you to avoid the transaction costs associated with saving at formal savings institutions. You need strong discipline to both avoid spending these savings yourself and deny the requests of other family members, furthermore, money saved at home does not earn any interest, and thus may lose value over time. Informal savings also encompass Iqubs, Mahiber and Iddirs savings mechanisms (Mwakajumilo, 2011).

SACCOs are user-owned financial institutions that offer both savings and credit services to their members. Members of these financial institutions can be both net savers and net borrowers. Depending on a country's legal framework, SACCOs may be authorized to mobilize member savings and non-members savings or member savings only. SACCO Society is financial cooperative society established by voluntary people based on the philosophy of building self-help society or "people helping people". SACCO society is owned, managed, controlled by members. Members have the right to decide on its issues, members have the right to benefit from its service. SACCO society is formed initially for the poorer to provide financial services such as safe place for savings and providing easy accessible loans to members. SACCO Society is "not for profit or for charity" but serve members at fair profit margins. In SACCO Society member's savings form a good pool of money, from which loans are made to members with fair lending interest and the interest rate is decided by members. And also in SACCO Society once overhead and other expenses are paid, reserve for cushion against any loss, and for expansion of services set aside, the remaining income from loans is returned back to members in the form of dividend on savings, share or both (Getachew, 2006).

There are different characteristics that makes SACCOs different from other cooperatives and financial institutions is that SACCO's operations are concentrated within their own membership and a person must be a member in order to save, borrow or receive other services from the SACCO. In developing SACCOS, working funds are comprised mostly of member shares; in mature SACCOs, working funds are mainly deposits. SACCOs' make loans to members, emphasizing primarily the character and ability to repay. SACCOs' rely to a significant extent upon the volunteer efforts of the members; the key element in the development of SACCOs' is volunteerism.

\subsubsection{Determinants of Saving performance}

The determinants of savings generally and the specific effects of government policies on savings is pivotal force in investment and economic growth. The level of savings depends on the marginal propensity to save of the players of the economy; this is the proportion of a small change in disposable income that would be saved, instead of being spent on consumption.It is computed by dividing the change in savings by the change in disposable income that caused the change. Savings also depend on the willingness and ability of individuals and corporate to save (Laurine, et al. 2013). There are some theoretical models in the literature which explains different determinants of savings and asset accumulations. Some of the determinants of saving will be reviewed as follows.

\section{Lack of awareness/lack of financial literacy}

Due to lack of awareness creation and lack of financial literacy training saving practice of member of SACCOs is very low and insufficient especially at rural area (Alemayehu, 2001)

\section{Income}

Both the Keynesian savings function and the permanent income hypothesis indicate a positive effect of income on savings (Keynes, 1936). Keynesian model explains that the motive behind savings is the desire to bequeath an estate. Disposable income is taken as the major determinant of individual savings in which people with a low income considered to be unable to save (Schultz, 2005 and Rijckeghem, 2010).

\section{Rates of Return}

The rate of interest is also considered to have an important influence on household savings. According to intertemporal consumption decision, an increase in the rates of return increases savings but real income effect of higher rates of return can affect savings adversely (Muradoglu, and Taskin, 1996). The net effect of income, substitution, and wealth make saving inelastic to increase in interest rates. However substantial increase in interest rates may bring changes to the saving level. As per the classical theory of interest rates, households are encouraged to save by higher interest rates. The higher interest rate make them substitute current consumption 
with savings

\section{Inflation}

The inter-temporal consumption argument suggests that inflation expectations may encourage expenditures on durables at the expense of savings. On the contrary, it is also suggested that inflation decreases the real value of financial wealth fixed in nominal terms, and households trying to restore their wealth-income position will increase their savings (Gary R. Evans, 2013)

\section{Employment}

This is an important determinant of savings since the more the people employed the more their ability to generate income that would be saved if not fully consumed, coming from another angle, if there are more people employed at one household this means that the income of one person is not exhausted in consumption but can be partly consumed and the remainder is postponed (Laurine, et, al, 2013).

\section{Demographic Factors}

As Muradoglu and Taskin (2007) mentioned, the dependency ratio which is defined as the share of population under age fifteen or over sixty-five is the most popular demographic variable used in savings literature. The young and the elderly are expected to consume out of past savings while the persons of working age are expected to accumulate savings.

\subsection{RESEARCH METHEODOLOGY}

The study adopted both qualitative and quantitative survey design as it aims at attempts to determine factors affecting saving practice of members of saving and credit cooperatives (SACCOs) in Gamo Gofa zone Kucha woreda. Survey design is appropriate where there is a need to take a sample size out of the population and then the data is collected and analyzed for inferential purpose.

In kucha woreda cooperative development office there were 56 SACCOs with membership size of 21,053. The researcher was taken 392 members based on simple random sampling method.

\subsubsection{Model Specification and OLS Assumption}

The regression model which was specified to analyze the data is as follows:

$\mathrm{Y}=\alpha+\beta \mathrm{x} 1+\beta \mathrm{x} 2+\beta \mathrm{x} 3+\beta \mathrm{x} 4+\beta \mathrm{x} 5+\beta \mathrm{x} 6+\beta \mathrm{x} 7+\beta \mathrm{x} 8+\beta \mathrm{x} 9+\mathrm{e}$

$\mathrm{LS}=\mathrm{f}(\alpha+\beta \mathrm{LI}+\beta \mathrm{AC}+\beta \mathrm{TP}+\beta \mathrm{SB}+\beta \mathrm{FC}+\beta \mathrm{Ag}+\beta \mathrm{DR}+\beta \mathrm{ED})$

Where,

LS - Level of annual Savings of members

$\alpha \quad$ Constant

LI - level of members annual income

$\mathrm{CA}$ - Access to credit

$\mathrm{TP}$ - training participation by members

SB - saving before membership

FC - Family members' contribution for livelihood Ag - Age of the member

ED - Education status of the member

DR - Dependency ratio

Implicitly the model is specified as Savings $=\mathrm{f}$ (income, credit access, training, saving before membership,

family members' contribution for livelihood, age, family size, education status, and dependency ratio). The $\alpha$ is the intercept and the $\beta$ s are the regression coefficients estimated while the es are the error terms designed to capture other confounding variables not included in the model.

In all the analyses, confidence level was held at $95 \%$ and $\mathrm{P}<0.05$ was set for significance level.

\subsection{DATA ANALYSIS AND DISCUSSION}

In conducting the study, 392 questionnaires were distributed out of which 392 were returned and answered. Therefore, the response rate is $100 \%$.

\subsubsection{Members Saving Practices before Joining SACCOs}

As table 1 below shows, majority of SACCO member's about354 (90.3\%) did not save in any form of financial institutions before joining the SACCO. Around 38(9.7\%) of the respondents replied that they have been saving after joined the SACCO. From the respondents about $22(5.6 \%)$ of them saved in micro finance institution and about $16(4.1 \%)$ of them saved in commercial bank of Ethiopia. 
Table 1: Saving and place of saving before joining the SACCOs

\begin{tabular}{|l|l|l|l|}
\hline \multicolumn{2}{|l|}{ Variable } & Frequency & Percent \\
\hline \multicolumn{2}{|l|}{ Respondents did not saving before SACCOs membership } & 354 & 90.3 \\
\hline \multicolumn{2}{|l|}{ Respondents saving before SACCOs membership } & 38 & 9.7 \\
\hline \multirow{2}{*}{$\begin{array}{l}\text { What financial institution } \\
\text { saving) }\end{array}$} & Banks(commercial bank) & 16 & 4.1 \\
\cline { 2 - 4 } & Omo micro finance & 22 & 5.6 \\
\cline { 2 - 4 } & Total & & $\mathbf{1 0 0}$ \\
\hline
\end{tabular}

\section{Source: survey data (2018)}

\subsubsection{Financial Literacy Trainings Provided by SACCOs}

Under this component the researcher found out that, out of 392 respondents about $187(47.7 \%)$ have received training on any finance topic compared with 205(52.3\%) have not received trainings on topic of any financial literacy .

Table 2: Respondents Financial Literacy Training participation and need

\begin{tabular}{|c|c|c|}
\hline Variables & Frequency & Percent \\
\hline Received training & 187 & 47.7 \\
\hline Not received training & 205 & 52.3 \\
\hline Total & 392 & 100 \\
\hline \multicolumn{3}{|l|}{ Organizers/providers of training/ } \\
\hline SACCOs & 69 & 17.6 \\
\hline NGOs & 40 & 10.2 \\
\hline Cooperative office & 131 & 33.4 \\
\hline House Hold Asset Building Program me(HABP) & 152 & 38.8 \\
\hline Total & 392 & 100 \\
\hline Any one who need training and not need traini & & \\
\hline Need training & 390 & 99.5 \\
\hline Not need training & 2 & 0.5 \\
\hline Total & 392 & 100 \\
\hline
\end{tabular}

\section{Source: survey data (2018)}

\subsubsection{Members income and saving}

The minimum annual income of members was Birr 2,160 while the maximum birr was 92,100 . The survey result showed that the average annual saving ranged from birr 63 to birr 3,112.00 with a mean of 281.82.

Table 3 below showed that SACCOs members in average saved annually Birr 3780 and their annual income was birr 48,210. It showed that each Sacco's member in average saved very less amount compared to annual income. Therefore, government bodies and other organizations gave attention and they were mobilizing the community about saving importance. 
Table 3: Members' income and saving

\begin{tabular}{|l|l|l|l|}
\hline Saving/income & N & Minimum & Maximum \\
\hline monthly saving & 392 & 30 & 300 \\
\hline Annual saving & 392 & 360 & 3600 \\
\hline Monthly income & 392 & 180 & 7675 \\
\hline Annual income & 392 & 2160 & 92100 \\
\hline
\end{tabular}

\section{Source: survey data (2018)}

The study tried to find out the saving practices of members in relation with credit accessibility. Credit access in this case measured by the amount of credit the members received from the SACCOs. As we could see from table 4 below, about 276(70.4\%) of members of SACCOs have received credit and about 116(29.6\%) of respondents didn't received credit. This showed that majority of members have accessed credit.

Table 4: Did you receive credit?

\begin{tabular}{|l|l|l|l|}
\hline Have you received Credit ? & Frequency & Percent & Valid percent \\
\hline Yes & 276 & 70.4 & 70.4 \\
\hline No & 116 & 29.6 & 29.6 \\
\hline Total & $\mathbf{3 9 2}$ & $\mathbf{1 0 0}$ & $\mathbf{1 0 0}$ \\
\hline
\end{tabular}

\section{Source: survey data (2018)}

\subsubsection{Multiple Regression Analysis Results}

Table 5 below presented the results of multiple regression analysis. The result indicated a significant amount of variance in the dependent variable which was explained by the independent variables included in the model. There were seven independent or explanatory variables included in the multiple regression analysis. Out of these seven variables, four variables were found to be statistically significant $(\mathrm{p}<.05)$ in affecting the saving practice of members of SACCOs which was measured by the average annual savings amount.

Table 5: Multiple regression analysis results on savings

\begin{tabular}{|c|c|c|c|c|c|}
\hline \multirow[t]{2}{*}{ Model } & \multicolumn{2}{|c|}{ Unstandardized Coefficients } & \multirow{2}{*}{\begin{tabular}{|l|}
$\begin{array}{l}\text { Standardized } \\
\text { Coefficients }\end{array}$ \\
Beta \\
\end{tabular}} & \multirow[t]{2}{*}{$\mathrm{T}$} & \multirow[t]{2}{*}{ Sig. } \\
\hline & $\bar{B}$ & Std. Error & & & \\
\hline $\begin{array}{l}\text { (Constant) } \\
\text { annual amount of income } \\
\text { have you received credit } \\
\text { have you received } \\
\text { training } \\
\text { were where you saving } \\
\text { before you joined the } \\
\begin{array}{l}\text { SACCOs } \\
\text { age of the respondents }\end{array} \\
\begin{array}{l}\text { education status } \\
\text { respondents of the } \\
\text { do the } \\
\text { contribute Family } \\
\text { livelihood? }\end{array} \text { To member }\end{array}$ & $\begin{array}{l}.270 \\
0.025 \\
0.0497 \\
54.124 \\
0.0340 \\
0.0233 \\
0.0243 \\
.393\end{array}$ & $\begin{array}{l}.441 \\
.045 \\
.067 \\
.063 \\
.105 \\
.093 \\
.034 \\
.068\end{array}$ & $\begin{array}{l}.118 \\
.332 \\
.090 \\
.273 \\
.113 \\
.456 \\
.276\end{array}$ & $\begin{array}{l}-.612 \\
1.878 \\
7.369 \\
1.949 \\
6.074 \\
2.490 \\
7.084 \\
5.773\end{array}$ & $\begin{array}{l}.541 \\
.000 \\
.034 \\
.000 \\
.062 \\
.0521 \\
.000 \\
.021\end{array}$ \\
\hline
\end{tabular}




\subsection{CONCLUSION}

Results of the study provided initial evidence on the factors that affected saving practices of members of rural and urban saving and credit cooperatives. Some of the variables included in the study had a strong significant relationship with the dependent variable savings, and where as some of them didn't.

The study showed that participation in training was the most important independent variable followed by education status of respondents, credit received and income level of respondents in case of sample SACCO members selected in the study area. It was revealed that rural poor individuals could save if they were provided with trainings or financial education, and appropriate financial products like credit availability as per their need, and their income level and education status were affected their saving level. This study tried to answer the research questions posed in the beginning of the study by revealing statistically significant relationships between the dependent variable saving and the independent variables: training, education status, credit, and income of members of SACCOs.

The other independent variables found had no statistically significant relationship with savings of members in the study area.

\subsection{RECOMMENDATIONS}

Based on the findings of the study the following recommendations were forwarded:

There is a need for enhancing trainings on different topics and mobilizing about saving to members of the SACCOs to increase their saving trend. Since all of the members in SACCOs were rural peoples with a very low literacy rate, training is the best way to literate them about savings and its benefits. In this regard, as the result of the study revealed, there is a need to focus on providing training to members in order to mobilize savings efficiently.

Over all from the results the researcher also saw that the major determinants of saving practices of members of SACCOS were financial literacy training. Therefore SACCOS should give high attention in attracting members to increase their amount of saving by providing awareness about the benefit of joining SACCOS by using different social Medias, by creating training programs, through distribution of brochure to clients etc. To be viable financial institutions, SACCOs should attract members to save by setting compatible interest rate that encourage members to save above forced saving that they take to banks.

Finally Federal cooperatives agency should pay attention continuously supervising of SACCOS as they helped many peoples in providing saving as well as credit services and they were one of the financial service providers that highly contributed for the outreach of financial services for the country.

\section{REFERENCES}

Adams, D. W. (1977) Mobilizing Household Saving through Rural Financial Markets. Ohio State University, pp. $547-560$

Alliance for Financial Inclusion, (2010) Formalizing micro savings a tiered Approach to Regulating Intermediation. Bangkok, Thailand.

Chowa, G.A.N., Masa, R.D., and Ansong D. (2012) 'Determinants of saving among low Income Individuals in Rural Uganda: Evidence from Assets Africa’, Advances in Applied Sociology, 2, pp. 280-291.

German Cooperative and Raiffeisen Confederation (2005) The Role and Importance of Savings and Credit Cooperatives in Micro financing and the World Wide Activities of the German Cooperatives and Raiffeisen Confederation.

Girma Teshome, Belay Kassa, Bezabih Emana, and Haji, J. (2013) 'Determinants of Rural Households Saving in Ethiopia: the Case of East Hararge Zone, Oromia Regional State', Journal of Economics and Sustainable Development, 4(3), pp. 66-75.

Nega, M.T., (2007). An Investigative Analysis into the Saving Behaviour of Poor Households in Developing Countries: With Specific Reference to South Africa. Unpublished MSc Thesis. University of the Western Cape. South Africa.

Nwachukwu, T.E., and Odigie, P. (2009) 'What Drives Private Saving in Nigeria', A paper presented at the centre for the study of African Economies (CSAE) conference: University of Oxford, March 2009.

Pailwar, V.K., Kaur, J., Saxena, K., Nijhara, M. (2010) 'Impact of Membership of Financial Institutions on Rural Saving: A Micro- Level study', International Business and Economics Research Journal, 9(10), pp. 139-148.

Pate, A. P., Shome, D. (2011) Do Households Still Prefer Bank Deposits? An Analysis of Shift in Savings and Saving Determinants. Unpublished. North Eastern Hill University, Meghalaya, India. 